Jurnal Konstruksi Hukum | ISSN: 2746-5055

Vol. 2, No. 1, Januari 2021 Hal. 41-45 | Tersedia online di https://www.ejournal.warmadewa.ac.id/index.php/jukonhum

DOI: https://10.22225/jkh.2.1.2965.41-45

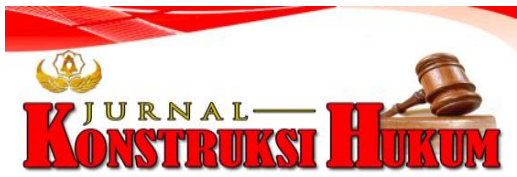

\title{
PELAKSANAAN EKSEKUSI BENDA JAMINAN KREDIT YANG TIDAK MENCUKUPI UNTUK PELUNASAN UTANG DI KOPERASI GUNA ARTA KARANGASEM
}

\author{
I Gede Agus Wira Sanjaya, I Nyoman Putu Budiartha, Desak Gde Dwi Arini \\ Fakultas Hukum Universitas Warmadewa, Denpasar-Bali, Indonesia
}

\begin{abstract}
Abstrak
Penelitian ini bertujuan untuk mengetahui perjanjian kredit atau pinjaman dana usaha antara nasabah dan koperasi dan mengetahui penyelesain apabila terjadi sengketa pada perjanjian kredit antara nasabah dan koperasi. Penelitian ini menggunakan metode penelitian empiris dimana metode tersebut berpacu pada hukum positif dan norma. Hasil penelitian menunjukan bahwa perjanjian yang dilakukan antara pihak koperasi dan nasabah atas kesepakatan para pihak yang siap melaksanakan kewajiban dan mendapatkan hak. Kewajiban pihak koperasi memberikan pinjaman dana kepada nasabah, hak koperasi mendapat keuntungan bunga dari pinjaman dana nasabah. Kewajiban nasabah membayar tepat waktu pinjaman yang telah disepakati karena telah meminjamkan dana, hak dari nasabah menadapatkan pinjaman untuk keperluan nasabah sesuai kesepakatan para pihak. Kemudian, kesepakatan para pihak bukan jaminan tidak terjadi wanprestasi, pentingnya kuasa hukum dalam sebuah perjanjian lebih memudahkan penyelesaian masalah antara para pihak. Kuasa hukum memberikan pilihan jalur mengakhiri perkara melalui pengadilan (litigasi) dan penyelesaian secara kekeluargaan (non litigasi). Kebanyakan pihak menggunakan jalur non litigasi karena ingin segalanya selesai dengan singkat namun biaya murah. Andai kata penyelesaian jalur non litigasi tidak menemukan titik tengah maka perkara dilanjutkan ke pengadilan. Aturan hakim berlaku bagi pihak yang berperkara mulai dari waktu sampai biaya yang dikeluarkan. Bagi pihak yang kalah bersedia dimintakan ganti rugi atas perbuatannya.
\end{abstract}

Kata Kunci: Eksekusi, Koperasi Simpan Pinjam, Setoran Pokok, Sertifikat Modal Koperasi

\begin{abstract}
This study aims to determine the credit agreement or business loan between the customer and the cooperative and to find out the settlement in the event of a dispute in the credit agreement between the customer and the cooperative. This study uses empirical research methods where the method is based on positive law and norms. The results showed that the agreement made between the cooperative and the customer is based on the agreement of the parties who are ready to carry out their obligations and get rights. The obligation of the cooperative to provide loan funds to customers is the right of the cooperative to benefit from interest from customer loan funds. The obligation of the customer to pay the loan on time that has been agreed upon because he has lent funds, the right of the customer to get a loan for the customer's needs according to the agreement of the parties. Then, the agreement of the parties is not a guarantee that there will be no default, the importance of a legal attorney in an agreement makes it easier to resolve problems between the parties. Legal attorneys provide options for ending the case through the court (litigation) and settlement in a family way (non-litigation). Most parties use the non-litigation route because they want everything to be done quickly but at low cost. If the non-litigation solution does not find a middle ground, the case will proceed to court. Judge's rule applies to parties in litigation from the time until the costs incurred. Those who lost are willing to be asked for compensation for their actions.
\end{abstract}

Keywords: Execution, Savings and Loans Cooperative, Principal Deposit, Cooperative Capital Certificate

\section{PENDAHULUAN}

Di era sekarang ini, uang menjadi yang utama bisa dikatakan dengan uang seseorang dapat memiliki apapun. Percaya tidak percaya Indonesia dapat bertahan karena pajak yang dihasilkan dari setiap penghasilan masyarakat serta meningkatkan perekonomian dari masyarakat dan nasional. Semakin padatnya penduduk maka semakin banyak orang yang memerlukan uang demi bertahan hidup. Koperasi merupakan solusi pemerintah dalam menekan angka kemiskinan namun demi bisa mendapatkan modal usaha harus mengisi formulir serta mengikuti syarat dan ketentuan. Lembaga keuangan merupakan alternatif terbaik saat ini bagi masyarakat yang ingin mengembangkan usaha demi meningkatkan sumber pendapatnya namun demi mendapatkan pinjaman dari koperasi 
diperlukan beberapa syarat seperti jaminan yang setara dengan modal yang ingin dipinjam serta ketentuan bunga yang berlaku disetiap koperasi berbeda-beda tergantung besar dana pinjaman. Sasaran koperasi ialah masyarakat dengan ekonomi menengah kebawah, biasanya jika ada masyarakat ekonomi menengah keatas akan dipertimbangkan terlebih dahulu baru diputuskan apakah mendapat pinjaman dana atau tidak namun bagi masyarakat ekonomi menengah kebawah akan dipermudah dalam proses peminjaman dana.

Koperasi juga memiliki fungsi yang sama seperti lembaga perbankan yaitu untuk menghimpun dana dan menyalurkan kembali kepada anggota koperasi. Sebagai organ social maka koperasi perlu mengutamakan dimensi kehidupan social yaitu peningkatan kualitas kehidupan masyarakat. Koperasi simpan pinjam menekankan pada bidang permodalan untuk mewujudkan tujuan dari koperasi tersebut maka masyarakat wajib bekerjasama dengan koperasi karena kerjasama ini akan menguntungkan kedua belah pihak. Kerjasama tersebut dilakukan dengan meminjam modal kepada koperasi bagi masyarakat yang membutuhkannya. Dalam memberikan pinjaman harus dilakukan dengan perjanjian kredit yang disepakati oleh peminjam. Dengan adanya perjanjian kredit ini di satu pihak, peminjam memperoleh kredit tersebut dengan harapan agar usaha yang dilakukan dapat berkembang dan dapat memenuhi kebutuhannya yang lain. Sedangkan pada pihak koperasi memperoleh keuntungan dari pemungutan bunga kredit. Disamping itu untuk menjamin pelunasan utangnya dalam perjanjian kredit tersebut, pihak peminjam diharuskan memberikan jaminan kepada pihak koperasi sebagai pelunasan utang apabila si peminjam suatu saat tidak bias melunasi pinjamannya kepada pihak koperasi. Jadi sudah seharusnya apabila masing - masing pihak dalam suatu perjanjian yang telah diadakan harus melaksanakan isi perjanjian yang telah disepakati.Setiap pihak yang melakukan perjanjian harus memiliki etikad baik yaitu mematuhi setiap isi perjanjian dan tidak melakukan wanprestasi yang berakibat batalnya suatu perjanjian (Harahap, 1986)

Para pihak melakukan perjanjian terlebih dahulu mendiskusikan isi perjanjian yang akan ditandatangani dan melaksanakan kewajiban demi menadapatkan hak. Jangan ada salah satu pihak tidak setuju namun perjanjian tetap dilaksanakan, hal tersebut membuat selisih paham yang berujung terjadi wanprestasi. Bila terjadi ingkar janji maka perjanjian tidak dapat berjalan lagi serta terjadi kemungkinan penuntutan hak oleh pihak yang merasa dirugikan, contoh wanprestasi sering terjadi di koperasi keterlambatan salah satu pihak membayar tagihan yang telah tertera pada perjanjian efek keterlambatan salah satu pihak tersebut mengakibatkan adanya denda oleh pihak koperasi. Wanprestasi tidak saja terjadi pada pihak koperasi dan nasabah namun bisa dilakukan oleh sesama anggota koperasi yang meminjam dana untuk keperluan pribadinya. Terdapat 3 golongan pinjaman, yaitu pinjaman lancer, pinjaman kurang lancer, dan pinjaman macet. Jika pinjaman atau kredit mengalami kemacetan hingga sampai pihak peminjam tidak memenuhi pelaksanaan perjanjian yaitu pelunasan kredit, maka jaminan si debitur akan ditarik oleh pihak koprasi sebagai pelunasan utang atau kredit si peminjam. Pihak Koperasi dapat mengajukan permohonan pelelangan jaminan tersebut ke Kantor Lelang Negara atau benda yang menjadi jaminan tersebut dapat dijual bersama-sama oleh pihak koperasi dan debitur guna mewujudkan pemenuhan prestasi yang menjadi haknya jika debitur ternyata melakukan wanprestasi. Perwujudan prestasi disini tidak memerlukan perantaran hakim karena debitur disini telah menyetujui cara demikian sesuai dengan isi dari perjanjian kredit yang telah disepakati. Pelaksanaan pemenuhan prestasi yang dilakukan sendiri oleh kreditur semacam ini disebut parate eksekusi atau eksekusi langsung.

Permasalahan yang timbul kemudian adalah di satu pihak, apabila setelah melakukan pelelangan atau penjualan benda jaminan milik debitur bersama-sama dengan pihak koperasi ternyata jaminan yang dibayarkan oleh debitur masih bernilai kurang atau jaminan tersebut tidak dapat mencukupi pelunasan utang kreditur kepada pihak koperasi. Sedangkan di pihak lain, pihak koperasi harus menuntut pemenuhan prestasi berupa pelunasan utang dari pihak debitur yang juga merupakan anggota koperasi. Terkait dengan masalah tidak mencukupinya hasil eksekusi benda jaminan kredit untuk pelunasan utang debitur kepada pihak koperasi, maka berdasarkan pemaparan latar belakang masalah dapat diteliti lebih jauh mengenai penyelesaian yang dilakukan oleh pihak koperasi dalam menuntut pelunasan utang debitur jika eksekusi benda jaminan kredit milik debitur ternyata tidak mencukupi untuk pelunasan utangnya.

Pada setiap perjanjian masing - masing pihak diwajibkan untuk memenuhi apa yang menjadi isi dari perjanjian atau dapat dikatakan bahwa masing - masing pihak wajib untuk memenuhi prestasinya, perjanjian kredit menimbulkan hak dan kewajiban bagi para pihak yang membuat 
perjanjian kredit. Sehingga dalam pelaksanaannya perjanjian kredit juga dapat menimbulkan akibat hukum bagi pihak kreditur dan debitur yang menyepakatinya.

\section{METODE PENELITIAN}

Penelitian ini menggunakan metode normatif dan kualitatis dimana dalam pengerjaannya peneliti menelaah isu hukum dengan didasari peraturan - peraturan hukum yang ada di Indonesia (Ahmad, 2008). Pencarian informasi secara normatif berpatokan pada peraturan pemerintah yang berfokus pada anak sebagai objeknya dan analisis dalam Informasi yang didapat secara konseptual berkaitan dengan penelitian ini. Penelitian hukum normatif adalah hukum kepustakaan yang mengacu pada norma hukum yang terdapat dalam peraturan Perundang-undangan (Waluyo, 2002). Pendekatan perundangan-undangan adalah melakukan suatu penelitian dengan berpatokan pada undang-undang sebagai dasar penyusunan penelitian ini. Pendekatan kasus dilakukan guna melihat, mencatat dan memahami permasalahan yang diangkat dalam penelitian ini dengan tidak keluar dari zona hukum positif.

\section{HASIL DAN PEMBAHASAN}

Apabila seseorang ingin meminjam modal usaha harus ada jaminan yang harga jualnya sesuai modal yang dipinjam, kegiatan ini dilakukan oleh lembaga - lembaga keuangan kepada nasabah atau anggota mereka golongan ekonomi menengah kebawah. Tidak semudah yang terlihat sebelum melakukan pinjaman harus mengisi formulir serta mengajak salah satu sanak saudara sebagai saksi telah dilakukannya perjanjian pinjam dana antara nasabah dengan pihak lembaga keuangan. Lembaga keuangan yang dibahas pada penelitian ini lembaga keuangan koperasi milik masyarakat dan menetap di hampir setiap desa - desa. Dalam melakukan suatu perjanjian para pihak harus sepakat mengenai isi perjanjian, para pihak yang bersangkutan secara bersama - sama terlebih dahulu mendiskusikan isi perjanjian agar tidak ada pihak tidak menyukai perjanjian. Tujuan perjanjian sendiri mempermudah para pihak untuk saling mendapatkan hak tanpa melupakan kewajiban, hal itu selalu ada diperjanjian. Para pihak harus memahami dasar perjanjian seperti arti kata sepakat, kewajiban dulu lalu mendapatkan hak, sanksi bagi pihak yang terbukti melakukan wanprestasi serta harus berisi kuasa hukum, nantinya kuasa hukum yang mengarahkan para pihak menyelesaikan perkara akibat wanprestasi salah satu pihak. Isi perjanjian kredit tersebut dari pihak debitur sudah harus mengerti akanisi perjanjian kredit tersebut, karena dalam perjanjian tersebut, debitur yang tidak melunasi utangnya sudah menyadari bahwa barang berharganya, baik barang yang bergerak maupun ynag tidak bergerak, baik yang sudah ada maupun yang akan ada dikemudian hari, akan menjadi jaminan dan koperasi akan menyita benda atau harta kekayaan milik debitur tersebut untuk menutupi kekurangan pelunasan utang debitur. Sesuai perjanjian kredit tersebut, maka pihak Koperasi dapat menyita benda - benda atau harta kekayaan milik debitur melalui penetapan pengadilan. Kemudian diajukan permohonan kepada kantor Lelang Negara untuk mengambil harta kekayaan debitur yang lain untuk melunasi hutang - hutang debitur.

Sebuah perjanjian yang memasukan kuasa hukum untuk mengamankan aset masing - masing jika suatu hari terjadi wanprestasi tugas kuasa hukum memberi pilihan penyelesaian sengketa mulai dari memakan waktu dan tenaga yang banyak sampai penyelesaian alternatif atau yang lagi buming belakangan tahun ini. Dua cara penyelesian sengketa yaitu litigasi dan non litigasi, keduanya memiliki aturan ketentuan berbeda. Mulai dari jalur litigasi, setiap pihak merasa dirugikan mengajukan gugatan melalui pengadilan, mempercayakan putusan dan aturan main oleh hakim ketua. Biasanya setiap orang yang melakukan litigasi sudah tidak menemukan titik terang dari negosiasi dari penyelesaian secara non litigasi. Aturan waktu serta pemanggilan beberapa orang yang menjadi saksi membuat proses litigasi berjalan lambat, butuh waktu beberapa bulan menyelesaikan tuntutan yang diajukan. Memilih jalur non litigasi atau jalur singkat penyelesaian masalah sangat tepat karena proses tidak membutuhkan waktu lama seperti jalur litigasi (Muhammad, 2006). Cara penyelesaiannya cukup mudah yaitu kedua belah pihak melakukan negosiasi atau mencari jalan tengah agar perjanjian kembali berlanjut dan selesai sesuai isi perjanjian yang sudah disepakati bersama. Secara meluas penyelesaian sengketa non litigasi dapat dilakukan efisien waktu dan dana tidak begitu besar yaitu:

1. Penjadwalan kembali (reschduling), yaitu perubahan syarat kredit yang menyangkut jadwal pembayaran atau jangka waktunya, termasuk masa tenggang, baik yang meliputi perubahan besarnya atau tidaknya angsuran. Tujuannya untuk debitur dapat menyusun dana langsung 
"cash flow" secara lebih pasti, memastikan pembayaran yang lebih tepat, memungkinkan debitur untuk mengatur pembayaran kepada pihak lain.

2. Persyaratan kembali (reconditioning), yaitu perubahan sebagai atau seluruh sayarat - syarat kredit yang tidak terbatas pada perubahan jadwal pembayaran, jangka waktu dana atau persyaratan lainnya sepanjang tidak menyangkut perubahan maksimal saldo kredit. Upaya ini bertujuan untuk menyempurnakan legal documentation, menyesuaikan kemampuan membayar debitur dengan kondisi yang terjangkau oleh debitur (angsuran pokok, denda, penalti dan biaya - biaya lainnya).

3. Penataan kembali (restructuring), yaitu perubahan syarat - syarat kredit yang menyangkut penambahan dana, konversi seluruh atau sebagai tunggakan bunga menjadi pokok kredit baru. Tujuan dari dilakukannya penataan kembali untuk memberikan kesempatan pada debitur untuk berusaha kembali melalui penambahan dana, memperbaiki kolektabilitas pinjaman debitur melalui tunggakan bunga, denda, pinalti, dan biaya - biaya lainnya.

Penyelesaian sengketa melalui Alternative Despute Resolution atau disebut non litigasi adalah penyelesaian sengketa diluar pengadilan berdasarkan kesepakatan para pihak dengan mengesampingkan penyelesaian sengketa melalui proses pengadilan (litigasi). Setiap permasalah pasti ada jalan tengah demi kebaikan kedua pihak, kebanyakan pihak yang mengambil jalur non litigasi permasalahannya selesai dengan waktu singkat namun tidak semua penyelesaian secara non litigasi menemukan titik tengah. Perselisihan antara pihak yang bersitegang bahwasanya pihaknya benar membuat non litigasi tidak dapat dilakukan maka beralih ke jalur litigasi (Sidik, 2008). Persetujuan hakim diperlukan sebelum memulai sidang perkara wanprestasi, menunggu selama seminggu minimal dilanjutkan pemanggilan pihak - pihak terkait dalam perjanjian seperti para pihak, saksi, pegawai koperasi yang menyaksikan perjanjian di buat. Akhir sidang memutus salah satu pihak keluar sebagai pemenang, jika pihak nasabah menang akan menadapatkan ganti rugi dari pihak koperasi, jika pihak koperasi menang dalam persidangan maka berhak melelang jaminan milik nasabah sesuai isi perjanjian serta berhak meminta ganti rugi apabila hasil jual barang jaminan nasabah tidak mencukupi hutang nasabah.

\section{SIMPULAN DAN SARAN}

\section{Simpulan}

Koperasi merupakan wadah bagi masrakat ekonomi menengah kebawah untu menabung, membuat modal usaha dengan cara melakukan perjanjian kredit atau pinjaman dana usaha. Perjanjian yang dilakukan antara pihak koperasi dan nasabah atas kesepakatan para pihak yang siap melaksanakan kewajiban dan mendapatkan hak. Kewajiban pihak koperasi memberikan pinjaman dana kepada nasabah, hak koperasi mendapat keuntungan bunga dari pinjaman dana nasabah. Kewajiban nasabah membayar tepat waktu pinjaman yang telah disepakati karena telah meminjamkan dana, hak dari nasabah menadapatkan pinjaman untuk keperluan nasabah sesuai kesepakatan para pihak. Kemudian, kesepakatan para pihak bukan jaminan tidak terjadi wanprestasi, pentingnya kuasa hukum dalam sebuah perjanjian lebih memudahkan penyelesaian masalah antara para pihak. Kuasa hukum memberikan pilihan jalur mengakhiri perkara melalui pengadilan (litigasi) dan penyelesaian secara kekeluargaan (non litigasi). Kebanyakan pihak menggunakan jalur non litigasi karena ingin segalanya selesai dengan singkat namun biaya murah. Andai kata penyelesaian jalur non litigasi tidak menemukan titik tengah maka perkara dilanjutkan ke pengadilan. Aturan hakim berlaku bagi pihak yang berperkara mulai dari waktu sampai biaya yang dikeluarkan. Bagi pihak yang kalah bersedia dimintakan ganti rugi atas perbuatannya.

\section{Saran}

Melalui penelitian ini diharapkan kepada Pemerintah, khususnya Dinas Perkoperasian supaya mengawasi dan memberikan pertimbangan serta jalan keluar terhadap permasalahan simpan pinjam atau kredit macet yang ada dikoperasi. Koperasi sebaiknya dalam pemberian kredit, Koperasi mengecek tentang kepastian terlebih dahulu mengenai benda jaminan tersebut dalam hal nilai dan jumlah jaminan, status kepemilikan dan daya tahan jaminan tersebut. Apabila hal tersebut sudah jelas dan pasti, maka jaminan yang diajukan boleh diterima dalam perjanjian kredit. Kemudian pihak Koperasi sebaiknya mengasuransikan benda jaminan kredit milik debitur kepada pihak asuransi agar dalam hal terjadi kecelakaan atau kerusakan pada benda jaminan, pihak asuransi dapat menanggung 
beban biaya dari kerusakan dari benda jaminan tersebut. Sehingga pihak Koperasi tidak mengalami kesulitan dalam pelaksanaan atas eksekusi benda jaminan kredit dalam hal pelunasan utang debitur kepada pihak Koperasi. Kemudian, Kepada masyarakat, lebih teliti melakukan perjanjian oleh pihak koperasi, ditelusuri prospek koperasi dari mulai disahkan sampai sekarang. Terkadang lembaga keuangan koperasi keuangannya tidak stabil atau sedang terlilit masalah yang nantinya membuat nasabah merugi. Akan lebih baik bertanya dari pada sesat dijalan. Lebih baik mengetahui seluk beluk koperasi terlebih dahulu sebelum melakukan perjanjian kredit atau peminjaman modal usaha.

\section{DAFTAR PUSTAKA}

Ahmad, B. (2008). Metode Penelitian Hukum. Bandung: Pustaka Setia.

Harahap, M. Y. (1986). Segi-Segi Hukum Perjanjian. Bandung: Alumni.

Muhammad, D. (2006). Hukum Perbankan Di Indonesia. Bandung: Citra Aditya Bakti.

Sidik, S. H. (2008). Hukum Jaminan Keperdataan. Jakarta: Sinar Grafika.

Waluyo, B. (2002). Penelitian Hukum Praktek. Jakarta: Sinar Grafika. 